Marlene Tamanini

Universidade Federal do Paraná

\title{
Novas tecnologias reprodutivas conceptivas: bioética e controvérsias
}

\begin{abstract}
Resumo: Este artigo trata de alguns dos múltiplos aspectos éticos/bioéticos e de gênero no campo das novas tecnologias reprodutivas conceptivas (NTRC). A literatura nele apresentada aponta para a pluralidade de situações e abordagens possíveis em um campo multidimensional e controvertido. Explicita alguns princípios éticos/bioéticos do agir biomédico encontrados durante pesquisa com casais heterossexuais que fizeram reprodução assistida e com médic@s especialistas em reprodução humana no Sul do Brasil. ${ }^{1}$ Apresenta os pressupostos éticos/ bioéticos sancionadores do agir médico e da continuidade dos chamados tratamentos para engravidar, e analisa os mecanismos utilizados para reerguer as expectativas dos casais em situação de desconfiança ou de insucesso.
\end{abstract}

Palavras-chave: tecnologias conceptivas, bioética, deontologia médica, gênero.

Copyright (c) 2004 by Revista Estudos Feministas

1 Este artigo é resultado da tese intitulada Novas Tecnologias Reprodutivas Conceptivas à luz da bioética e das teorias de gênero: casais e médic@s ao Sul do Brasil, defendida no doutorado interdisciplinar em Ciências Humanas do Centro de Filosofia e Ciências Humanas da Universidade Federal de Santa Catarina em março de 2003. Agradeço à CAPES a bolsa concedida durante o doutorado e no período do doutorado sanduíche na França, de setembro de 2001 a março de 2002.

2 Estou usando o símbolo @ para masculino e feminino no caso da referência aos entrevistad@s, e para designar o campo da

\section{Introdução}

As Novas Tecnologias Reprodutivas Conceptivas (NTRC) são um campo multidimensional envolto em variadas controvérsias, desde aquelas que envolvem uma multiplicidade de sujeitos - o casal heterossexual e homossexual; as mulheres casadas ou solteiras; os homossexuais, tanto as lésbicas solteiras quanto os gays; os médic@s² (obstetras, ginecologistas, geneticistas, embriologistas, urologistas, etc.) - quanto as que dizem respeito aos laboratórios e às clínicas (no caso brasileiro, as clínicas privadas), ou ainda ao contexto e às condições em que se desenvolvem. Chamadas de tratamento, elas separam no tempo e no espaço a fecundação e a gestação, a maternidade gestativa e a genética, e permitem a um homem estéril vir a ser pai biológico ou adotivo, o que, aqui, assume uma característica particular, ou seja, a de uma adoção pré-concepção do filho da mãe 
biomedicina, como um construto tanto de homens como de mulheres, no caso dos médic@s. com material genético de outro homem ou com um embrião fornecido por outro casal. Também permitem a paternidade adiada, em caso de homens vasectomizados que recorrem mais tarde ao seu esperma congelado, ou de homens que sofreram quimioterapia e depois fazem inseminação artificial. Há ainda o caso dos que têm embriões congelados e os utilizam posteriormente, ou os casos de morte do marido em que é feita posteriormente a transferência de embriões para o útero da esposa.

Além desses inúmeros aspectos, todos portadores de possíveis discussões no campo da ética/bioética e gênero, impossíveis de serem tratados neste artigo, mas que se apresentam como desafios enormes e ao mesmo tempo como um campo prazeroso para a produção de novos entendimentos teóricos e práticos, há que se considerar que esses investimentos tecnológicos e sociais na busca pelo filho, de preferência do próprio sangue, perturbam também a definição de sexo biológico e a distinção entre sexo e gênero. Considere-se também que esses investimentos nos reportam ao sentido construído pelos envolvidos na busca pelo filho como razão primeira de sua vida, na maioria das vezes uma busca que perdura durante anos, quando são enfrentados inúmeros insucessos, a preços nem sempre acessíveis, com grandes sacrifícios afetivos, emocionais e econômicos. Eles nos reportam também aos riscos físicos e psico-emocionais a que são submetidas as mulheres durante o tratamento e aos possíveis problemas com gravidez múltipla ou com trigêmeos, conforme foi constatado nessa pesquisa. Tudo para ter um filho a quem transmitir o DNA parenteral.

Considerem-se também os aspectos jurídico-legais e o movimento feminista, que, mesmo em sua heterogeneidade, conserva desconfianças sobre a reprodução assistida, no que se refere ao sexismo, à medicalização dos corpos femininos e à permanência das desigualdades inter e intragênero.

As possibilidades de interferência cientificotecnológica sobre o embrião quando fora do útero abrem outras novas questões. Elas envolvem os diagnósticos préimplantacionais, a escolha de sexo, a superprodução embrionária e sua destruição ou criopreservação, a clonagem de embriões, o seu implante fora do ventre da mulher que o gerou, ou sua destruição, quando a legislação permite, ou quando isso não se constitui em um dilema de consciência para os envolvidos, uma vez que o estatuto do embrião provoca grandes dilemas éticos, pois para muitos se trata da destruição de uma vida. Essa situação é freqüentemente encontrada entre os casais entrevistados no Sul do país, ${ }^{3}$ especialmente entre as mulheres, que muitas 
vezes se referem ao embrião como "meu filho que está lá congelado". Entretanto, os homens do casal e os médic@s, na maioria das vezes, consideram que são apenas células em processo de desenvolvimento. O embrião pode ser ainda objeto de experiências ou de pesquisas científicas, assunto que tem suscitado inúmeros debates, uma vez que a procriação através da fecundação in vitro muda essa relação. O embrião se torna, seguidamente, um objeto de que se pode dispor, e cujo destino está nas mãos dos envolvidos, situação expressa muito bem em uma das frases explicitadas durante uma das entrevistas com os médic@s. Quando perguntei sobre o destino dos embriões e sobre o porquê da reprodução assistida, não se reproduziu a mesma polêmica gerada em torno do aborto. Um dos 16 entrevistad@s me disse: "Você quer que eu faça o que com os embriões? Sopa?".

Assim poderiam ser nomeadas inúmeras situações que se apresentam como novas questões para a sociedade contemporânea e para o campo dos valores e da ética, particularmente no que diz respeito às novas possibilidades que permitem não tratar mais a esterilidade como uma fatalidade, nem deixar mais a natureza fazê-lo por conta própria. O poder da medicina permite hoje ajudar a natureza e atender ao querer do casal, conforme relatado em todas as entrevistas, tanto com os casais como com os médic@s, para quem o querer do casal, a categoria casal infértil e ajudar a natureza se transformam em princípios éticos do agir. Seu poder engendra novas filiações e implica o controle dos excessos e dos riscos. Ao mesmo tempo, coloca-se o direito à procriação e à justiça eqüitativa do acesso de forma igualitária aos serviços de saúde, o que, no caso da reprodução assistida, envolve recursos, procedimentos e discussões sobre as prioridades para o sistema de saúde brasileiro, segundo os entrevistad@s. Considerem-se também as condições de desinformação e de fragilidade econômica psico-emocional e afetiva em que essas decisões são tomadas.

A forma como as possibilidades são apresentadas pela mídia por um lado desmistifica o método, mas por outro gera expectativas e demandas nem sempre éticas, visto que quase sempre apresenta essas tecnologias como solução para a ausência do filho, mas pouco permite pensar sobre os conteúdos éticos/bioéticos e os modelos de filiação e de parentesco envolvidos nessa busca.

Tratando-se da reprodução assistida, nota-se sobremaneira o modo como no Brasil o Conselho Federal de Medicina (CFM) tem se atribuído a responsabilidade sobre a normatização do campo, transformando as regras de conduta profissional do médic@em parâmetro para 
${ }^{4}$ DINIZ, 2000.

${ }^{5}$ DINIZ e Samantha BUGLIONE, 2002.

6 Sobre direitos sexuais e reprodutivos ver: Maria Betânia ÁVILA, 1997 e 1999; Geneviève FRAISE, 1995; Adriana PISCITELLI, 1998a e 1998b; Denise DORA, 1998; Margareth ARILHA, 1998; Rosalind PETECHESKY, 1999; e Vera SOARES, 1997.

${ }^{7}$ Marilena CORREA, 2000.

${ }^{8}$ PHARO, 2001. julgar a sociedade, conforme tratado por Débora Diniz, ${ }^{4}$ que também alerta para o fato de que o direito brasileiro não a considerou como um problema a ser regulamentado. ${ }^{5}$ Segundo Diniz e Buglione, é preciso considerar que as implicações sociais, políticas, morais e sanitárias dessas práticas exigem a presença de suporte jurídico para proteger os direitos e interesses dos envolvidos. Esses aspectos foram constatados durante os processos de acompanhamento dos casais entrevistados na ocasião do trabalho de tese e, posteriormente, em conversas com casais que desejavam saber sobre esses procedimentos.

Acrescente-se que, no estudo em questão, os casais se deparam com a desigualdade, a vulnerabilidade, a ameaça à integridade corporal e o impedimento de acesso justo, que são pressupostos fundamentais dos direitos sexuais e reprodutivos, objeto de grande debate nos vários enfoques feministas. ${ }^{6}$

Reporta-se aqui também ao desejo de parentesco biológico, à essencialização da maternidade e do casal com filhos. Apesar da proliferação de instrumentos jurídicos, permanecem sem resposta inúmeras questões, somadas ao desconhecimento sobre a real situação da reprodução assistida no Brasil.?

Trata-se portanto, de problemas teórico-práticos, conforme definidos por Patrick Pharo. ${ }^{8}$ Problemas esses que ora exigem respostas emergenciais sobre a melhor maneira de agir, de acordo com as convicções morais e religiosas dos envolvidos, ora posições coletivas e reflexões filosóficas no que concerne à formulação do bem e do mal, da lei moral ou jurídica, além de envolver discussões sobre os direitos dos indivíduos, sobre os grandes princípios da autonomia, da beneficência, da não-maleficência e da justiça, desafios a serem assumidos como parte da sociedade e da vida comunitária. Portanto, são dilemas que implicam mais do que decisões individuais, comportando conseqüências sociais, políticas e econômicas que envolvem as populações e a humanidade como um todo. No caso das NTRc, envolvem as mulheres e sua autodeterminação, sua discriminação, assim como a necessidade de pesquisas sobre a infertilidade e também o processo coletivo de decisões para um controle democrático.

Os dilemas éticos/bioéticos surgem de um contexto sociocultural em uma dada época. Na particularidade deste artigo, elegemos alguns aspectos em meio a uma imensa variedade e complexidade de questões e de controvérsias existentes no campo das NTRc.

O primeiro aspecto sobre o qual trataremos traz alguns conteúdos para a discussão das questões que dizem respeito à ética/bioética e à deontologia médica. No 
${ }^{9}$ MEHL, 1998.

10 DINIZ e IBIAPINA, citados por Sérgio COSTA e Débora DINIZ, 2001. segundo, focaremos aspectos éticos/bioéticos que aparecem como pressupostos para o agir médico e os mecanismos utilizados para soerguer a expectativa dos casais diante de situações de desconfiança e insucesso.

\section{1. Ética/bioética, seus conteúdos e a deontologia médica}

A complexidade crescente de situações e as inúmeras controvérsias envolvidas nas NTRc permitem afirmar que o debate ético/bioético emergente em suas práticas tem mudado ao longo do tempo.

Na França, por exemplo, segundo estudos de Dominique $\mathrm{Mehl}^{9}$ a partir de artigos divulgados na imprensa, os conteúdos que fizeram parte dos debates em bioética se distinguem claramente, pelas temáticas apresentadas, em dois períodos. Um primeiro período, de 1982 ao nascimento de Amandine em 1992, tem como temática central a relação entre ciência e costumes e por principais protagonistas o mundo científico e o mundo intelectual. Quatro temas permanecem em debate nessa fase: o primeiro diz respeito à medicalização da procriação, e o segundo, ao desejo de filhos. Já o terceiro tema versa sobre os costumes e levanta questões como: será a medicina da reprodução unicamente reservada aos casais heterossexuais? O dom de gametas é moral? Devemos usar a barriga de aluguel? Que tipo de filiação se quer? A filiação biológica? Finalmente, o quarto tema diz respeito às relações entre a vida privada e a vida pública. O tom desse período é favorável às novidades anunciadas pelos progressos científicos.

O segundo período, que focaliza o embrião e o eugenismo e registra o crescimento da elite políticoadministrativa, desenvolve-se de 1992 a 1995, no Parlamento. Gira em torno do embrião e das questões que marcam as constelações e posicionamentos políticos a esse respeito, tais como: onde começa a vida? O que fazer com os embriões supranumerários? Pode-se fazer pesquisa com embriões não implantados? Há também uma segunda temática, a que diz respeito ao eugenismo e que levanta os seguintes questionamentos: podem-se realizar diagnósticos genéticos sobre os embriões antes da implantação? Podem-se eliminar fetos portadores de problemas genéticos?

A tonalidade dos discursos desse período é menos favorável aos avanços científicos e resulta na lei de bioética de 1994, que foi revisada em 1999.

No Brasil, embora não haja muita publicação em língua portuguesa ou de autores brasileiros, segundo Débora Diniz e Sérgio Ibiapina ${ }^{10}$ a disciplina tem sido apresentada 
${ }^{11}$ MOTA e OLIVEIRA, 2000.

${ }^{12}$ OLIVEIRA, 2001.

${ }^{13}$ DINIZ e Dirce GUILHEM, 2002. de várias maneiras. Pode ser identificada uma abordagem histórica, que remete ao nascimento da bioética e aos eventos do passado, e uma abordagem filosófica ou uma abordagem temática, que é dominante na bioética brasileira, tanto na disciplina quanto nos temas midiáticos. Segundo Antonio Joaquim Mota e Fátima de Oliveira, ${ }^{11}$ a bioética é uma disciplina e um campo de lutas, que aglutina diferentes movimentos sociais e personalidades democráticas. Nesse sentido, abarca as posturas mais diversas, desde aquelas que exaltam os avanços científicos, como aquelas que os rechaçam. A bioética, antes de ser uma disciplina, segundo Oliveira, ${ }^{12}$ estabeleceu-se como movimento social. A disciplina é uma decorrência do movimento pela ética na assistência e na pesquisa em saúde. Portanto, segundo a autora, ambos têm objetivos comuns: a busca do bom e do melhor para o ser humano e a humanidade, em determinado contexto social. A bioética envolve ainda, segundo Diniz e Guilhem, ${ }^{13}$ o reconhecimento das experiências práticas e morais em relação às mulheres e incorpora uma critica das práticas que determinam a opressão.

No campo das NTRc, a crítica às formas de opressão foi tomada como luta política pelo movimento feminista, que, em sua categorização chamada radical, assume o mais absoluto rechaço, denunciando as opressões de gênero, os riscos, a reessencialização da natureza na maternidade. Como alguém pode escolher se tem que ser? O movimento feminista denuncia os discursos pautados sobre a vulnerabilidade das mulheres e das crianças e que acabam por legitimar idéias sobre o cuidado como necessidade essencializada no seu ser - ou as essencializações que tomam a mulher como mais cuidadosa e sensível por natureza. Em sua corrente mais liberal, que toma a medicina reprodutiva como ajuda às mulheres, considera que ela é uma ferramenta de empoderamento das mulheres, pois ampliaria suas possibilidades de escolhas reprodutivas. Essa posição, no entanto, pode jogar contra a autonomia e a saúde das mulheres, quando agregada à lógica de mercado e ao poder da medicina e quando não são consideradas as condições socioeconômicas e culturais em que as mulheres fazem suas escolhas. Há, no entanto, um acordo geral de que a experiência da infertilidade se constitui em um sofrimento imenso para quem deseja ter um filho, ainda que consideradas as condições sócio-históricas da construção do desejo.

Um dos grandes problemas é que a realização do desejo dos homens e das mulheres configura uma base valorativa apropriada para uma ética da possibilidade, vinculada à idéia de irreversibilidade do progresso, mas não 
${ }^{14}$ Noëlle LENOIR, 2001.

${ }^{15}$ LENOIR, 2001

${ }^{16}$ TAMANINI, 2003

17 TESTARD, 1999.

${ }^{18}$ CORREA, 1997.

${ }^{19}$ Muitos dos aspectos relativos a esses riscos foram desenvolvidos nos estudos de Françoise Laborie, como LABORIE, 1992a, 1992b, 1992c, 1993, 1994a e 1994b.

20 Abordagens vindas da psicanálise, ou em diálogo com o campo, sobre essa dimensão foram desenvolvidas por: MarieJosèphe Levy DHAVERNAS, 1999; Silvia TUBERT, 1996; MarieMagdeleine CHATEL, 1998; e Sylvie FAURE-PRAGIER, 1998 e 1999.

${ }^{21}$ BATEMAN, 1999. vinculada ao cumprimento das obrigações sociais politizadas. Embora seja levado em conta, em algum nível, o respeito à decisão individual do casal, não há respeito ao princípio da justiça como inclusão no efetivo acesso à saúde, porque não é uma ética igualitária: 'Se não tem dinheiro ou se o dinheiro acaba, não se faz'.

Nesse quadro, sabe-se que o ser humano (a mulher) poderia usufruir dos imensos benefícios trazidos pela biogenética, mas também que ele se vê meio humano, meio animal, meio técnica. Ele faz a natureza, na medida em que introduz gens humanos em outras espécies ou em humanos, e de outras espécies em si mesmo. ${ }^{14}$ Essa troca entre espécies, como processo de construção/desconstrução e reconstrução inerente ao campo científico, pode trazer à tona muitos aspectos sobre a vida antes nunca vistos. ${ }^{15}$

Antigos medos em relação ao uso da vida humana e a tentativas eugenistas são considerados, enquanto se configura o desejo de equilibrar ao máximo as 'formidáveis' possibilidades terapêuticas oferecidas por essas novas possibilidades. A isso se acrescenta 0 fato de que as mulheres que buscam essas formas paliativas da infertilidade essencializam a experiência do gestar, amamentar e dar à luz em seu próprio corpo ${ }^{16} \mathrm{com}$ o uso de métodos dessas novas tecnologias que Ihes permitam fazer um filho em laboratório. Ao mesmo tempo, respondem às cobranças sociais que lhes exigem a maternidade como forma de felicidade e completude pessoal, no seio de uma família no modelo tradicional.

Ainda que essas mulheres estejam inseridas no contexto geral e amplo das biotecnologias, nem elas e nem seus companheiros se perguntam por que deveriam usar uma tecnologia que põe em questão a relação do ser humano com a natureza, incluindo a modificação desta, e que nasceu da transposição de práticas veterinárias para o domínio da reprodução, conforme tratado por Jacques Testard $^{17}$ e por Marilena Correa. ${ }^{18}$

O debate ético/bioético entre os casos mencionados pode dar-se ao redor da manipulação da vida, seja para interrompê-la, seja para recriá-la; ou ainda pode discutir a forma como essas técnicas são desenvolvidas e os seus riscos ${ }^{19}$ sobre a saúde e sobre os desejos do outro. ${ }^{20}$

Segundo Simone Bateman, ${ }^{21}$ as tecnologias, como assistência médica à procriação e sua entrada na intimidade sexual do casal, percorreram um longo caminho desde as primeiras experiências em biologia no século XVIII, sua passagem discreta para a prática médica no século XIX e sua condenação pelo Vaticano em 1897. Esses fatos acabaram por favorecer, na medicina, a construção da idéia de que se tratava de práticas terapêuticas, nublando, 
22 BATEMAN, 1999.

desse modo, as objeções morais. Os progressos na criopreservação dos espermas permitiram, segundo a autora, uma separação no tempo e no espaço entre o doador e a receptora e, igualmente, as condições do anonimato, para evitar o escândalo moral de uma mulher casada ser inseminada com o esperma de outro homem.

Segundo a autora, há que se considerar que a instrumentalização do ato de fecundar, combinada às possibilidades de criopreservação e de diagnóstico genético, abriu opções reprodutivas. Seguindo a maneira como cada técnica evoluiu, pode-se ter uma idéia sobre o futuro da procriação medicalmente assistida, como é chamada na França.

Na primeira etapa, uma técnica do corpo é substituída por técnicas instrumentais. Na inseminação artificial (IA) ou fertilização in vitro (FIV) são os gametas do casal que servem à fecundação, e isso é feito pelo médic@. É um ato técnico-instrumental que se justifica pela vontade de contornar os obstáculos fisiológicos. Na segunda etapa, os atos técnico-instrumentais praticados pelo médic@ fazem interferir uma contribuição genética ou fisiológica de uma pessoa exterior ao casal (inseminação com doador) - dom de esperma ou de embrião. Essa contribuição se justifica pela vontade de suprir a infertilidade, aparentemente incurável no estado atual dos conhecimentos médicos, mas se contrapõe às normas jurídicas e sociais de filiação. Essa prática ganha sentido na medida em que dá a esse tipo de transação o estatuto de ato médico e não de conduta sexual ilícita. Na terceira etapa, a técnica instrumental transforma-se em alternativa socialmente aceitável, um meio legítimo de conceber fora de toda justificação de ordem médica. A evolução, nessa terceira etapa, se apresenta à primeira vista como ruptura (afinal, pais celibatários e homossexuais, mães de aluguel, inseminação pós-morte poderiam encontrar seu lugar). Para alguns, isso representa possibilidade de escolhas; para outros, a perda dos referenciais fundantes da vida em sociedade.

Para Bateman, ${ }^{22}$ o que importa é ter presente que em cada escolha técnica, seja na ultrapassagem dos ditames morais, seja na construção do ato terapêutico, estáse mexendo com o registro corporal, psíquico e social, vindo do sexual. Isso transforma o simbólico, de onde a procriação tira seu sentido e no qual as condições antropológicas são colocadas em jogo cada vez que se trata de fazer uma escolha entre muitas possibilidades técnicas. As tentativas de evitar problemas de saúde, de ordem social e familiar ou de ordem moral, podem resultar também em outros problemas. 
${ }^{23}$ BATEMAN, 1999.

${ }^{24}$ BATEMAN, 1998.

${ }^{25}$ PETECHESKI, 1999.

${ }^{26}$ CORREA, 2001.

27 Wilza PEREIRA, 2000.

${ }^{28}$ LABORIE, 1993, 1994b, 1999 e 2000.

29 ROTANIA DE POZZI, 1999.

${ }^{30}$ OLIVEIRA, 1997.
Segundo Bateman, as interrogações morais sobre essas práticas provêm principalmente do fato de que, independentemente de visarem a uma conduta terapêutica na assistência à procriação, elas se constituem em uma atividade procriativa que independe das relações sexuais. Dentro de nossa sociedade, o modelo de referência em matéria de conduta procriativa é a relação sexual entre um homem e uma mulher, modelo que, independentemente do valor social anexado a uma procriação voluntária, remete ao que parece ser a ordem natural das coisas.

Para a autora, desde que a relação técnica com a procriação se torna instrumental, a situação dos procriadores muda. No plano corporal, há uma fragmentação e uma extensão, no tempo e no espaço, da experiência procriativa e, em alguns casos, da exteriorização do processo de fecundação e gestação. No plano relacional, os protagonistas implicados na concepção assistida são mais numerosos e diversamente qualificados; os meios técnicos e os materiais biológicos necessários à procriação não são somente controlados pelo casal. No plano institucional, a fecundação não se revela mais um ato íntimo do casal, mas um ato médico. No plano decisional, não é um ato do acaso, já que exige um posicionamento de escolha. O interesse ético se coloca então dentro de um quadro que se constitui em um agir moral.

No caso dos médic@s, um certo número de questões éticas relativas à procriação, conforme Bateman, ${ }^{23}$ levam especificamente às obrigações deontológicas, concernentes às exigências de controlar para o bem, eliminando os riscos a que se submetem suas pacientes. Essas obrigações concernem também às condições dentro das quais essas práticas se desenvolvem e ao dever de propor uma resposta terapêutica apropriada, além da informação clara sobre os cuidados que serão dispensados aos clientes. O problema é o de como se pode assegurar que essa ação seja sempre bem conduzida e dentro do respeito às pessoas. ${ }^{24}$ Todo esclarecimento que o médico possa fazer é condição para garantir a continuidade do 'tratamento', mas não garante, por si só, nem os critérios do bem, nem da integridade corporal. ${ }^{25}$

Vários estudos indicam aspectos da intervenção e da medicalização biomédica sobre a reprodução humana ou sobre o corpo feminino, como os de Marilena Corrêa, ${ }^{26}$ Wilza Pereira ${ }^{27}$ e Françoise Laborie,$^{28}$ tanto no que diz respeito aos aspectos mercadológicos, associados ao consumo e à transferência biotecnológica no campo das tecnologias genéticas e moleculares, conforme tratados por Alejandra Rotania de Pozzi ${ }^{29}$ e por Fátima Oliveira, ${ }^{30}$ como no que diz respeito à fixação realizada pelas intervenções médicas sobre o corpo a fim de incrementar o bem-estar com uma 
31 SOMMER, 1999.

32 SCAVONE, 1999.

${ }^{33}$ DINIZ e GUILHEM, 2002.

${ }^{34}$ Ver: TESTARD, 1999 e 2001 ; Irma VAN DER PLOEG, 1999; Laurence TAIN, 1999; Ann SAETNAN, 2000; e Hélène ROUCH, 2002.

35 BATEMAN, 2001. expectativa razoável de êxito, sem considerar as questões sobre os efeitos políticos, sociais e econômicos da utilização desses recursos, conforme tratada por Susana Sommer. ${ }^{31}$ Referem-se ainda à contradição entre a conquista dos direitos de cidadania ligada à reprodução e a imposição de políticas demográficas que usam tecnologias nocivas à saúde, nas quais as desigualdades são mais acentuadas, para que os direitos se transformem em deveres, retirando da luta por esses direitos seu sentido mais profundo - a politização, o domínio do corpo e a transformação das relações de gênero -, contradição essa tratada por Lucila Scavone. ${ }^{32}$

Outras questões dizem respeito, segundo Diniz e Guilhem, ${ }^{33}$ ao surgimento de uma consciência crítica sobre esse processo de medicalização da ausência de filhos, que vem provocando um intenso debate sobre como considerar as técnicas reprodutivas: são sinônimo de tratamento médico ou não? Trata-se da inserção social, política, moral e sanitária da medicina reprodutiva. A tendência da classe médica é considerar essas práticas como capazes ou de curar a infertilidade, ou de remediar a ausência indesejada de filhos, em um esforço terapêutico para concebê-los. Nesse sentido, seu principal objetivo é a produção de bebês, sendo pouco incentivada a pesquisa sobre as causas da infertilidade ou da baixa fecundidade. Esses aspectos são também apresentados criticamente em grande parte da literatura internacional consultada. ${ }^{34}$

Todas essas situações e suas possibilidades se desenvolveram de acordo com a forma como se constituíram e se delinearam na história os modos de procriar possibilitados pelo campo da biomedicina.

Segundo Bateman, ${ }^{35}$ na primeira vez em que um médic@se aventurou a propor como solução à infecundidade de um casal uma técnica substitutiva das relações sexuais, ele, de certo modo, redefiniu o campo de suas competências profissionais e dos atos que lhe eram permitidos. Na seqüência, ele se deu o direito, em seguida transformado em dever, de paliar a infecundidade que ele não podia curar. O importante dessa prática é o fato de que que se tornou aceitável a um médic@ agir diretamente na concepção de outro ser humano, organizando desse modo quadros próprios de uma deontologia médica para a ação e explicitando os parâmetros a serem levados em conta.

A própria noção de competência profissional é ampliada, o que, na opinião de Bateman, não se reduz a uma competência técnica. Ela aponta para outros deveres e responsabilidades, que devem levar em conta a totalidade das situações das pessoas que solicitam os serviços, além das condições em que os atos prescritos serão 
${ }^{36} \mathrm{Jacob}$ RENDTORFF e Peter KEMP, 2000; ROTANIA DE POZZI, 1999.

37 BATEMAN, 1999.

${ }^{38}$ TAMANINI, 2003 praticados e dos resultados desses atos, uma vez que, no caso da reprodução humana, não se trata de ter como objetivo curar uma doença, mas se trata da concepção de um ser humano.

Mesmo que as terapias paliativas sejam práticas correntes na medicina, no caso da procriação medicalmente assistida, segundo a autora, os médic@s se encontram diante de uma realidade sem precedentes, já que essa técnica tem a particularidade de substituir a relação sexual, pelo menos com a penetração técnica necessária à fecundação.

Desse modo, todas as questões remetem ao princípio deontológico de não prejudicar a saúde, mas dizem respeito a situações muito mais amplas como: de quem depende a decisão? Sobre que bases ela deve ser tomada? Quem arca com as conseqüências? Com quem são partilhadas as responsabilidades das conseqüências e das decisões?

Coloca-se igualmente a necessidade de considerarmos a amplitude de realidades presentes no ser humano que vão para além do que possa significar seu aspecto genético, biológico.

Considerem-se a estrutura genética e a integridade corporal, que são heranças de direito para as futuras gerações, ${ }^{36}$ sem deixar de levar em conta, segundo Bateman, ${ }^{37}$ as dificuldades para se pensar a dimensão sexuada da fecundidade e da gestação e a parte respectivamente diferenciada que se refere a cada sexo, reportando-nos às desigualdades de gênero. ${ }^{38} \mathrm{O}$ estado de infertilidade associado ao casal não é tratado mais como uma patologia física; ele cria uma unidade indiferenciada, o que faz com que a mulher seja assimilada como a provedora de gametas, mesmo criando um certo igualitarismo com a entrada do homem no processo reprodutivo. A partilha na participação não é igualitária, pois a maioria dos procedimentos continua se desenvolvendo nos corpos femininos, embora encontremos a medicalização masculina ou, em casos extremos, a microcirurgia para retirada de gametas do epidídimo.

Se a mulher é considerada apenas como uma portadora de gametas, uma vez que o estado da infertilidade é associado ao casal, será impossível analisar que a participação do homem e a da mulher sejam diferentes em cada etapa do processo. Eventualmente, a etapa mais complicada para o homem será a de colher seu espermatozóide via ato masturbatório, enquanto que a mulher, além da ingestão acentuada e gradativa de medicamentos, faz também os exames ecográficos, a retirada de óvulos com analgesia e punção, a subseqüente transferência, com espera pelo implante embrionário, 
${ }^{39}$ TELLES, 2001.

acompanhada de exames laboratoriais intensivos nos primeiros 14 dias, a ultra-sonografia e o acompanhamento pré-natal, sempre cheio de dúvidas e inseguranças. Acrescente-se ainda a marcação de cesariana, para a maioria dos casais entrevistados, tão logo se constate o 'andamento normal' da gravidez, mesmo que não haja impedimentos a priori para que se faça parto normal, além do medo de perder a criança com todo o investimento que ela significa.

É opinião unânime, tanto na literatura feminista consultada quanto na literatura médica, que no caso da injeção intracitoplasmática de espermatozóides (ICSI) as dificuldades masculinas são favorecidas. Essa técnica possibilita a paternidade ao homem que tenha a quantidade mínima de espermatozóides, que tenha apenas um ou tenha células precursoras, as espermatites, evitando, nesse caso, que ele recorra a um doador, mas a mulher precisa assim mesmo ser medicalizada.

Pode-se pensar que, comparando-se com o passado, há um certo igualitarismo entre a mulher e o homem, já que hoje ele é inserido no processo reprodutivo, dirimindo assim o entendimento histórico de que a esterilidade é somente um problema feminino e que o desejo de filhos é condição para o reconhecimento do ser mulher. Encontramos aqui elementos indicadores da inclusão do homem, na busca por reprodução assistida, como projeto de conjugalidade heterossexual, que se expressa na busca pelo filho do próprio sangue.

Ao entrar nesse campo, o homem expõe publicamente seu corpo, escolhe participar do tratamento, desloca a paternidade do cuidado dos filhos para a escolha consciente de fazer um filho em laboratório, e paga para isso. Esse fato traz a necessidade de ampliar estudos no campo da paternidade para perceber o que significam essas escolhas. Ao mesmo tempo, a participação do homem poderá vir a ser eliminada, se ele somente fizer a doação de gametas, na medida em que há indicativos da possibilidade futura de fazer embriões somente com óvulos, sem espermatozóides.

Segundo Fábio Telles, em notícia divulgada pela British Broadcasting Corporation (BBC), cientistas australianos encontraram uma maneira de fertilizar óvulos usando material genético de qualquer célula do corpo e não somente o esperma. ${ }^{39}$

A criação de bebês em laboratório a partir do desenvolvimento da procriação assistida levanta problemas éticos dos mais variados, se considerarmos, por exemplo, a doação de espermas ou óvulos. Verificamos que essa técnica é usada se o número de espermatozóides é muito 
40 JOUANNET, 2001.

${ }^{41}$ SOMMER, 1999.

42 Embora, segundo Sommer, tenha surgido uma série de intentos para regular essas práticas que incluem o consentimento das receptoras e seus parceiros, existe o segredo da identidade dos doadores eaté a limitação do número de vezes que seu esperma pode ser usado dentro de uma certa área geográfica. Sabe-se que os bancos de esperma que seguem as regras fixadas pela Sociedade Americana de Fertili-dade e pela Associação de Ban-cos e Tecidos têm sido obrigados a rechaçar até $80 \%$ a $85 \%$ dos doadores em potencial (SOMMER, 1999).

${ }^{43}$ Danielle NOGUEIRA, 2000.

${ }_{44}$ Sabe-se que a doação de esperma é aceita na Alemanha, Bélgica, França, Suécia, Noruega e Dinamarca, enquanto a doação de óvulos não é aceita na Bélgica, França e Dinamarca. No Líbano, a doação de óvulos é permitida, desde que usada pelo marido da doadora, ou seja, na situação única em que o homem possui mais de uma esposa, entretanto a doação de espermatozóides não é permitida, em qualquer hipótese (José Gonçalves FRANCO JUNIOR, 2002). ${ }^{45}$ RIBEIRO, 2002 baixo e se existe um problema hereditário/genético sério, como o caso da transmissão de mucovicidose, tal qual relatada por Pierre Jouannet. ${ }^{40}$ Ou ainda o uso de espermatite (proibido na França), possibilitado pela ICSI, o que também pode interferir na integridade genética.

A recepção/doação de material genético é um dos aspectos mais polêmicos também do ponto de vista das relações parentais envolvidas nessas escolhas quanto aos seus efeitos sobre a paternidade e a maternidade.

Entre as controvérsias imbricadas nos métodos utilizados em reprodução assistida, uma delas diz respeito ao efeito sobre as relações maritais e de parentesco, devido à assimetria que significa a mãe como a única relacionada geneticamente. ${ }^{41}$

Outras preocupações tratam dos efeitos psicológicos sobre a criança, tanto quando se mantém em segredo sua origem, quanto quando se informa sobre a sua concepção. ${ }^{42}$ Ao mesmo tempo, surgem velhas discussões que avançam para o campo do direito, como, por exemplo, se a paternidade está restrita ao vínculo biológico ou social.

Nas ciências humanas, é consensual o vínculo social da paternidade, mas no direito está em tramitação no Congresso Nacional brasileiro projeto de lei que torna obrigatório para as mães que receberam embriões revelar aos filhos as identificações dos pais biológicos. ${ }^{43}$ Essa é uma questão bastante controvertida na maior parte dos países onde se aceita a doação de esperma. ${ }^{44}$ Instaura-se ainda uma confusão evidente entre a paternidade e a doação como um contrato que se realiza pela transferência de propriedade do bem por liberalidade. O que não é levado em consideração é que a doação só existe no interesse dos casais e que o doador participa como um terceiro interveniente da técnica, o qual jamais planejou uma filiação advinda desse ato. A concessão legal de investigação de paternidade está retomando, no campo do biodireito em particular, a tentativa de estabelecimento de um vínculo natural, em detrimento do vínculo socioafetivo.

Existem inúmeras dificuldades. A primeira surge, segundo Diaulas Ribeiro, ${ }^{45}$ porque a Constituição brasileira não contemplou o tema da identidade genética, e quando se trata de uma criança nascida com sêmen de um fornecedor não correlacionado (doador de sêmen), passase de um doador anônimo para um caso de paternidade anônima, situação que também não é tolerada pela Constituição do país. A Constituição, ao proibir o anonimato, estabeleceu um princípio: segundo o autor, ninguém pode sofrer restrição de direitos individuais, salvo nos casos previstos em lei, com processo judicial integrado por ampla defesa e contraditório, mas ninguém pode usufruir de tais 
${ }^{46}$ RIBEIRO, 2002, p. 44.

${ }^{47}$ RIBEIRO, 2002.

${ }^{48}$ OLIVEIRA, 2000.

${ }^{49}$ Resolução do Conselho Federal de Medicina $n^{\circ} 1.358 / 92$. direitos anonimamente, pois o exercício de direitos fundamentais pode gerar obrigações fundamentais, que nada mais são do que a violação de direitos fundamentais alheios. Ninguém está proibido de procriar, mas ninguém pode, no atual sistema jurídico nacional, procriar sem assumir as obrigações da perfilhação (a obrigação de pai para com a criança).

Embora o Conselho Federal de Medicina (CFM) preveja essa situação, segundo o autor, na Constituição Federal não há espaço para a presença de doador anônimo de sêmen. A criança gerada com esse recurso da medicina reprodutiva poderá investigar a paternidade $e$ obrigar o Estado a lhe fornecer os elementos necessários, inclusive o nome do ascendente genético.

Segundo Ribeiro,

Poderá, ainda, exigir indenização por danos morais e materiais do médico, do hospital, do banco de sêmen e do próprio Estado, tendo como causa para pedir a forma de sua concepção, os danos psicológicos sofridos pela discriminação de ter sido criada sem pai, por não ter tido uma vida social compatível com a verdade genética, por não ter convívio familiar com os seus iguais e os danos materiais pelas conseqüências dessa concepção, como, por exemplo, o enlace de irmãos anônimos e a degeneração da prole. ${ }^{46}$

O mesmo se dá em relação à barriga de aluguel, proibida no nosso sistema legal, que adota o critério da autoria do parto como regra para a definição da maternidade. ${ }^{47}$

Outro aspecto tão ou mais polêmico diz respeito à redução de embriões que já se encontram no corpo da mãe. Isso ocorre em função do número de embriões implantados, para evitar o nascimento de mais de um bebê, caso se desenvolvam todos os embriões (até quatro, cujo implante é recomendado pelo CFM). Segundo vários autores, entre eles Oliveira, ${ }^{48}$ a redução de embriões é um dos muitos dilemas da medicalização da procriação, problema esse encontrado por mim entre os casais, situação para a qual, na maioria das vezes, o casal não está preparado. Sua busca sempre foi pelo filho. Como conviver agora com a necessidade de tirar um embrião? Observouse, nesse caso, que a situação resultava das deficiências da prática médica, da tecnologia ainda rudimentar, que insiste, por razões afetivas e comerciais, em querer demonstrar ser um sucesso absoluto, sem dar a devida importância à biossegurança da mulher, implantando mais embriões do que o organismo humano é capaz de aceitar com segurança.

A prática que ultrapassa $o$ implante de quatro embriões é ilegal no Brasil, segundo o $\mathrm{CFM},{ }^{49}$ além de 
${ }^{50}$ A taxa de gestações quádruplas no Brasil é quatro vezes maior do que nos EUA e, segundo reportagem da FSP/OESP do dia 4 de abril de 2000 , isso se deve à transfe-rência para o útero de um número maior de embriões do que o recomendado. Casos recentes de quíntuplos apontam que essa norma no Brasil pode estar sendo desrespeitada (BOLETIM, 2000).

${ }^{51}$ Embora haja uma recomendação de que seja até cinco anos. ${ }^{52} \mathrm{O}$ projeto relatado pelo senador Roberto Requião (PMDB-PR) proíbe o congelamento, estabelecendo que só podem ser produzidos quatro embriões, que devem ser transferidos para o útero sem deixar sobras. Segundo reportagem da revista Época, alguns médic@s transferem os embrióes para o útero da paciente na véspera da menstruação ou fora do período ovulatório. "Assim, eles são eliminados naturalmente. Isso evita o dilema ético", diz Dirceu Pereira, diretor da clínica Profert, em São Paulo (Dirceu PEREIRA, 2000 e 2002). Atualmente circula na Comissão de Assuntos Sociais do Senado, sob a relatoria do senador Tião Viana (PT-AC), o Projeto de Lei 90/99, do senador Lúcio Alcântara (PSDB-CE), que inicialmente permitia a transferência de no máximo quatro embriões e a manutenção de embriões em criopreservação por até dois anos. Mas hoje, por pressões durante o processo de tramitação do Conselho de Constituição, Justiça e Cidadania do Senado, em que o senador Requião atuou como relator, ele passa a estabelecer, se for aprovado, até três embriões e proíbe o congelamento de embriões humanos.

$53 \mathrm{O}$ consentimento informado implica a compreensão do ato terapêutico. Trata-se de um processo e não de uma assinatura em um formulário, e se funda na noção de autonomia. Caracterizase por uma informação adequada (mas não necessariamente completa), pela capacidade do indivíduo de compreendê-la e pela sua liberdade de decisão.

54 Marcela IACUB e Pierre JOUANNET, 2001.

${ }_{55}$ MATTEI, LABORIE O NOVAES, 1995. apresentar dois problemas: a vida e a saúde das mulheres são colocadas em risco, ${ }^{50}$ e não foi definido o que fazer com as sobras de embriões. O Conselho Federal de Medicina também não estabelece o tempo máximo de congelamento, o que produz um contínuo crescimento de embriões criopreservados. ${ }^{51}$

O problema se agrava por fatores outros, como o alto número de pacientes que abandonam o tratamento ou que não desejam mais engravidar após o sucesso com as técnicas de reprodução assistida. Ainda parece não haver população interessada em receber embriões doados, pois o material genético do embrião, e do futuro filho, não pertencerá a nenhum dos integrantes do casal infértil, resistência também encontrada nos casais que entrevistei.

No caso de morte ou separação do casal, ou se o mesmo desaparece ou deixa de pagar a taxa de manutenção, o problema fica com as clínicas de fertilização, que devem seguir a norma do Conselho Federal de Medicina, que proíbe o descarte de embriões. "Eliminálos é como assassinar alguém", disse o senador Roberto Requião (PMDB-PR), relator de um dos três projetos de lei sobre reprodução assistida que atualmente tramitam no Congresso. ${ }^{52}$

Ainda há que se ter em conta o desconhecimento sobre o quanto são respeitados a ética e o consentimento informado ${ }^{53}$ quando da realização das novas tecnologias conceptivas. Minha pesquisa fornece indícios de que os casais não são informados ou não são suficientemente informados sobre os possíveis riscos durante o processo de tratamento. O que encontrei, sempre que perguntei, é que o médic@ Ihes falara sobre os percentuais de sucesso e de fracasso dessa tecnologia. Penso que isso seja uma forma de autoproteção diante da tecnologia ainda bastante experimental, o que nos coloca face a face com outra questão: estamos diante de um tratamento para a infertilidade ou de pesquisas, que, como não se mantêm análises dos dados na maior parte das clínicas, também não irão contribuir para a mudança desses experimentos? Há ausência quase completa de critérios coletivos e amadurecidos socialmente capazes de construir parâmetros de análise fora do contexto puramente médico. ${ }^{54}$

Faz-se ainda necessário, segundo Jean-François Mattei, Françoise Laborie e Simone Novaes, ${ }^{55}$ pensar a direção da própria profissão médica, a qual, para eles, nos últimos 20 anos está em plena mutação, que resulta em quatro modalidades responsáveis pela perda de direção: 1) a tecnológica - alguns médicos se apresentam mais como cientistas do que como humanistas. Um técnico tem prazer em colocar em obra a técnica de congelamento, de 
inseminação, de ICSI, e para isso ele encontra palavras nobres e nela sua razão de ser. Engenheiro em maquinaria humana, ele se afasta do humanismo, que responde a um sofrimento; 2) a econômica - o médico é mais e mais constrangido pelos custos e balanços, mais preocupado pelo equilíbrio financeiro do serviço de sua clínica, do seu gabinete ou de sua estrutura de cuidado, e confunde o comércio e a prática. É isso que motiva sua ligação com a tecnologia, que pode ser um modo de retirar vantagem da clientela, de melhorar o seu balanço, pois se sabe que, em um primeiro momento, a medicina se ancorou mais sobre as novas tecnologias por medo de perder os seus clientes; 3) a midiática - o desejo de ser o primeiro a fazer alguma coisa, de ter seu nome no jornal. A notoriedade de um médico depende da quantidade de aparições e de sua notoriedade pública; 4) a administrativa - cada um acredita desobrigar-se de sua responsabilidade através de uma nota administrativa a seu superior hierárquico. O resultado é a transferência de responsabilidade individual para a irresponsabilidade coletiva.

As tentativas de regrar essas ações, passando as questões pertinentes aos comitês de ética, ainda são muito limitadas. Talvez também não sejam o melhor caminho, uma vez que o cotidiano dessas práticas exige por si mesmo uma equipe interdisciplinar capaz de avaliar e julgar cada situação à luz da ética diária. Essa não é simplesmente uma ética que deriva de princípios legais, mas é uma ética introjetada, respirada e levada em conta em qualquer situação que envolva uma decisão sobre tratamento.

O quadro geral traçado até aqui aponta já uma infinidade de questões. A segunda parte do artigo trata de alguns dos pressupostos éticos/bioéticos construídos pelos casais e médic@s e que permitem o agir médico e a manutenção das expectativas em situações de desconfiança ou insucessos nesse campo minado e multidirecional que é o campo das NTRc.

\section{2. Ética/bioética e os pressupostos do agir médico}

A intervenção médica cotidiana na reprodução humana parte do pressuposto de que é necessário ajudar a natureza, devolvendo sua capacidade reprodutiva, que está em algum lugar e que necessita ser acordada e ajudada pela ciência.

Desse modo, a medicina tratará de transformar 0 corpo infértil, deixando-o em condição de manifestar fertilidade, a partir de um entendimento de que essas intervenções são naturais, pois são utilizadas para imitar o trabalho da natureza. Tomadas como relação de ajuda à 
56 TAMANINI, 2003.

57 Judith BUTLER, 1999. natureza sexuada dos corpos, elas perdem seu caráter maléfico, ganhando em benevolência, ao mesmo tempo que capacitam a reprodução na espécie humana.

Assim, compreendidas como forma de ajuda, as tecnologias são pouco questionáveis, não cabendo interrogá-las sobre o poder que elas dão à ciência médica de agir sobre a vida, nem sobre o corpo das mulheres. Nelas há objetos privilegiados, as mulheres, na medida em que as diferenças fisiológicas reprodutivas e as diferenças de sexo requerem a manipulação dos corpos centrada no corpo feminino.

Na fala dos entrevistad@s médic@se,em parte,na dos homens do casal, constata-se a idéia do abraço entre a natureza e a técnica enquanto entidades que se completam e buscam normalizar o casal. Para eles, a tecnologia não muda o processo de fazer um filho; ela apenas acerta as condições físicas.

Aqui é a técnica agindo na barriga que torna a natureza fértil - a barriga é natural -, já que manter o bebê na barriga permite construir a naturalidade do processo de procriar. O entendimento é o de que, se há algo artificial, é só na relação de ajuda ao natural; o desenvolvimento do bebê continua sendo no corpo natural. Ele não é autônomo e, nesse caso, poder-se-ia colocar a barriga a seu serviço. A barriga está sendo ressaltada para focar a naturalidade do processo. Enquanto a barriga e o útero forem escolhidos como fundamentos do processo natural, permitir-se-á manter a linguagem centrada na naturalização do processo.

A dicotomização de gênero presente na forma particular de contraposição entre o útero $e$ o espermatozóide ${ }^{56}$ apresenta-se também quando se fala da natureza como uma entidade inscrita tanto no corpo do homem como no da mulher, e que é revelada, por exemplo, nas expressões "usamos materiais humanos", ou seja, espermatozóides e óvulos. Ao mesmo tempo essa dicotomização é externa aos gametas, porque engaja sentidos de outra lógica, a de que é natural para uma mulher ser mãe, e reporta-nos ao papel social naturalizado. A mulher é vista como mãe biológica e o homem deve ser pai porque é o marido da mãe. Desse modo, a construção do sexo não é um dado corporal sobre o qual o construto do gênero é artificialmente imposto, mas é uma norma cultural que governa a materialização dos corpos como materialização da norma regulatória. ${ }^{57}$

No que tange ao primeiro aspecto, relativo à identidade sexual inscrita no corpo, segundo os médic@s ela é então capaz de dotar os corpos com uma essência marcada de modos diferentes. Generosa com o homem e 
58 É a divisão celular que é apontada como o critério fundamental para a escolha dos embriões. São selecionados aqueles que apresentam menos fragmentações, os que obtiveram uma divisão celular adequada ao tempo proposto. Não há como avaliar outros aspectos, por exem-plo, os elementos químicos. É por isso, segundo alguns entrevista-d@s, que, mesmo obtendo embriões considerados ruins, pode-se ter sucesso, chegando-se a uma gravidez. perversa com a mulher, essa natureza marca a mulher com a incapacidade porque lhe faltam óvulos ou o útero. $O$ homem é apenas marcado com uma falha, conforme nos dizia uma das entrevistadas, comentando a fala de outros a respeito do marido. "Eles diziam 'tu és um falhado'". Nesse particular, as tecnologias de reprodução assistida, do ponto de vista dos médic@s, são ajuda que vem devolver a capacidade reprodutiva da mulher, de fora para dentro, via medicação. Também recuperam a falha no corpo masculino, mas de dentro para fora, via ICSI, sendo que o corpo masculino é concebido como naturalmente fértil, podendo sua potencialidade ser desenvolvida por meio de uma ajuda tecnológica, que vai buscar até mesmo células imaturas, as espermatites, para utilizá-las via ICSI. O gameta masculino é preparado e capacitado para ser recolocado no curso como fértil, portanto potencializado através de um poder biomédico/laboratorial sobre o corpo. A prática médica reforça as concepções culturais de que o homem é sempre fértil, enquanto a mulher é mais necessitada de ajuda tecnológica. Seu corpo, seu útero e seus ovócitos continuam sendo partes imprescindíveis para as NTRc, mas ela tem que normatizá-los via medicação e intervenção corporal.

Segundo os médic@s, a tecnologia é capaz de devolver para a mulher o que ela perdeu ou não tem, ao mesmo tempo em que potencializa o homem no que ele tem, na busca de resultados reprodutivos. Esse é o trabalho da ICSI, que demanda uma escolha dos espermatozóides por parte do biólogo. Ele escolhe os que considera os melhores, ${ }^{58}$ através de critérios morfológicos, para materializar o embrião. Quando não há espermatozóide, nem no ejaculado e nem no epidídimo, trabalha-se com a maturação de espermatite (células precursoras de espermatozóides).

O primeiro ponto que nos chama a atenção ao levarmos em conta as justificativas médicas para realizar a reprodução assistida é que encontramos uma série de apoios de linguagem e, ao mesmo tempo, de entendimentos que permitem a continuidade dos esforços de tratamentos, ainda quando eles são difíceis. Expressões como "é o sentimento da pessoa", "se a pessoa quer a gente vai fundo", "a vida é efêmera e rápida", "respeitar a verdade da pessoa" aparecem o tempo inteiro nas falas dos médic@s.

Para eles, o querer do casal legitima sua prática, e é sobre o querer do casal que agem, tecnicamente falando. Diante dos impasses dos insucessos, é sempre o querer do casal que conta em primeiro plano. Entenda-se aqui querer do casal como realmente do homem e da mulher, porque dificilmente é possível continuar se um dos dois se recusa 
durante o processo, mesmo se a maior parte das intervenções se desenvolve no corpo da mulher.

O médic@ apresenta-se como aquele que deve manter a neutralidade, considerando sempre em suas recomendações os valores dos casais. Segundo a concepção de que a liberdade de escolha para eles é essencial, seria injusto não oferecer possibilidades de fazêla de modo completo, entendida como acesso a uma FIV/ ICSI ou, em casos mais simples, a uma inseminação artificial.

Isso não significa, porém, como poderia sugerir à primeira vista, respeito à autonomia do casal, mas, em grande parte, apenas a manutenção das condições de intervenção. Esta por si só não garante nem saúde, nem a ausência de abusos e a escolha procriativa segura.

Dessa insistência sobre o querer do casal, o médic@ permite-se dizer que:

a) enquanto o casal não desistir, ele não desiste, porque a meta é o filho, não importa quantas vezes tenha que fazer o procedimento técnico, médico, laboratorial. Isso é justificado por um entendimento subliminar explicitado deste modo: "Estou tentando ajudar alguém a ser feliz", "Estou tentando ajudar alguém a realizar um desejo", "Faço tudo o que posso", "A maternidade é um instinto, uma paixão que não passa e precisa ser realizada";

b) outro pressuposto que precisamos levar em conta é o fato de que o médic@ tem sido o único profissional na equipe a estabelecer critérios de autoridade para definir continuidade ou desistência durante o tratamento. Muitos dos casais entrevistad@s também delegam a ele essa decisão. Alguns médic@s disseram durante as entrevistas que, quando avaliam criticamente as reais possibilidades apresentadas por um casal, bem como a oferta tecnológica capaz de responder àquela demanda, podem levar em conta a relação custo-benefício, as dificuldades econômicas do casal, bem como o seu desgaste emocional (do médic@, dos homens e mulheres envolvidos) e concluir que não vale a pena continuar. Mas a grande maioria não considera essa possibilidade - apenas uma médica nos informou que ela pode eventualmente se recusar a fazer diante de outras razões, como, por exemplo, quando se trata de pacientes portadores de doenças;

c) quando o médic@ não chama para si essa decisão, então ele transfere toda a responsabilidade para o casal, colocando-se no lugar de instância esclarecedora. Isso, ao mesmo tempo em que cumpre as determinações sobre o consentimento informado, pode também eximi-lo de suas responsabilidades éticas, principalmente se o casal conhece os limites, os riscos e as incógnitas do processo e, ainda assim, deseja continuar. O médic@ pode alegar, até 
${ }^{59}$ BATEMAN, 2001.

60 MATTEI, LABORIE O NOVAES, 1995. pela falta de uma equipe que pondere e verifique as reais motivações do casal, que essa decisão está fora de sua responsabilidade. Na fala dos casais, há um consenso de que o médic@ deva sofrer alguma forma de controle, pois, segundo eles, mesmo que o médic@ seja considerado como uma ajuda para seus problemas de infertilidade, nem sempre os interesses dele são convergentes com os seus. "É muito fácil o médic@ te manipular",conforme expressa um dos homens entrevistados.

Considere-se também que muitas vezes, deixando a decisão para o casal, ele decide sem os critérios do conhecimento científico (supõe-se que a equipe deveria tê-los). Pudemos verificar entre os nossos entrevistad@s decisões que não se dão somente sobre a continuidade dos procedimentos, mas sobre qual procedimento fazer em primeiro lugar: "A médica queria fazer inseminação, mas nós decidimos fazer o proveta de uma vez. Não deu certo, depois fizemos inseminação e deu certo".

Em alguns casos, os protocolos não são suficientes e as situações complexas poderiam ser analisadas por uma equipe interdisciplinar. Trata-se de situações não previstas, tanto na situação de superovulação, como quando as mulheres resistem às orientações médicas: "Eu não escutava", "não adiantava ele falar comigo, eu só enxergava o filho". Além disso, um olhar interdisciplinar poderia permitir recolocar as questões sobre os limites e possibilidades de sucesso/ insucesso, acompanhando-se assim a percepção das reais motivações envolvidas na busca. Ou trata-se de situações em que são exigidas mais do que informações, quando é necessária a mediação entre os próprios pressupostos da deontologia médica, conforme tratados por Bateman, ${ }^{59}$ e as necessidades impostas pelas novas situações. Ou de casos em que a profissão médica tomar direções outras, não previstas, ou dentro de perspectivas questionáveis, conforme tratadas por Mattei. ${ }^{60}$ Considere-se, ainda, a relação do médic@ com a clínica, o modo como ele mantém a continuidade do seu trabalho, o modo como ele constrói a credibilidade nos procedimentos, pois é possível que isso abra caminhos para a interferência da subjetividade na escolha da técnica a ser utilizada.

Também pode haver situações em que há insistência da parte da mulher ou do casal, envolvimento emocional do médic@ com o desejo de filhos do casal e necessidade de divulgar o trabalho da clínica, que são alguns aspectos, entre outros, que podem interferir no processo. Nesse caso, a cumplicidade pode se dar tanto quando o casal assume as proposições que o médic@ Ihe faz, quanto quando, ao contrário, o médic@ se submete ao gosto do casal. O fato é que, sem cumplicidade, não há como colocar esses procedimentos em 
${ }^{61}$ Conforme BATEMAN, 1998; e MATTEI, 1995.
${ }^{62}$ GIDDENS, 1991. ação. Isso pode comprometer as ações no sentido da benevolência e do respeito à integridade do processo. ${ }^{61}$

Entretanto, vários textos feministas e a literatura sobre direitos sexuais e reprodutivos apontam inúmeros problemas com essas práticas. Existem situações que só podem ser identificadas durante o 'tratamento'. Alguns dizem respeito à relação médico-casal; outros se apresentam no momento de administrar a frustração em relação a um ciclo perdido. Nessa hora há muitas dúvidas, desconfianças e constatações de erros que se interpõem, além da carga de frustração, que é imensa diante de um insucesso ou de uma expectativa não concretizada quanto ao resultado de um exame ou de um comportamento médico. Esses aspectos levam os casais (quando persistem) e os médic@s a refazerem as regras do relacionamento e do tratamento, caso a caso.

Todo o investimento, tanto do casal quanto do médic@, é realizado no sentido do reerguimento das expectativas para poderem continuar intervindo. Essa atitude, na verdade, tem também um efeito de parceria $e$ cumplicidade que elimina o fator crítico da parte do casal e permite ao médic@ administrar o risco. Em caso de insucesso futuro, ele estará protegido porque informou. Ao mesmo tempo, mantida essa cumplicidade, terá até em certo nível o apoio do casal envolvido, que poderá até dizer: "Mas ele foi honesto, tentou".

Além dos problemas apresentados até aqui, há muitos outros. Podemos apontar a administração das frustrações, a medicação e o seu uso, a hiperovulação, a discussão sobre a qualidade do material, as dificuldades com a ausência de nidação, os critérios racistas e eugenistas, o pedido de exames considerados desnecessários, o implante de todos os embriões e a redução embrionária, a idade da mulher, os erros médicos, a continuidade ou abandono do tratamento, o preço e os diferentes pacotes de pagamento que são discutidos em cada tentativa.

Esses pontos de conflito, a construção da natureza fértil e a concepção das intervenções como naturais revelam a necessidade de ancorar esses elementos em outros aspectos. Eles envolvem as relações com a confiança, o afeto, a técnica e o médic@ e dizem respeito à chamada qualidade do material, à pressão social e familiar e às questões relativas à sexualidade. Todas essas questões estão carregadas de possibilidades e ambigüidades passíveis de interferir na demanda por reprodução assistida, bem como no processo do tratamento convencionado:

a) a confiança nesse estudo, de acordo com Anthony Giddens, ${ }^{62}$ aparece como um elemento fundamental, indicando que um tratamento proposto por meio dessas 
${ }^{63}$ Marilyn FRANKLIN, 1990.

tecnologias deverá ser capaz de unir o esforço técnico e a dimensão afetiva, em situação de ignorância. A confiança na conduta dos médic@s e na capacidade das tecnologias como condição para o tratamento está também na fala dos casais. Esse elemento revela traços de funcionalidade para a manutenção da relação de interdependência entre os envolvidos: médic@s e casais. Ele é capaz de se contrapor ao chamado desespero da mulher, ${ }^{63}$ permitindo administrar aquilo que é apresentado como surpreendente ou imponderável pelo próprio médic@, quando as expectativas de sucesso criadas a partir da observação do material colhido são frustradas ou quando o embrião não nida. Ainda diante dos impasses e da ignorância sobre o melhor caminho a ser assumido no tratamento ou diante da necessidade de clareza na atitude, é a confiança que permite a continuidade do relacionamento.

Ela viabiliza também a constituição dos aspectos técnico-laboratoriais e a partilha de recursos humanos entre as clínicas. O elo de confiança, nesse caso, dá-se sob o velcro do nome do médic@ ou do biólogo que lhe presta assessoria. Isso, por um lado, permite a montagem de um serviço de reprodução assistida que é localmente desejado. Por outro lado, abre novas frentes às clínicas consolidadas, ao mesmo tempo em que oferece um serviço próximo e menos dispendioso do ponto de vista do acesso e da locomoção. Mas deixa sempre no ar uma pergunta sobre quanto, de fato, ele trabalha com elementos controlados e confiáveis. Quanto mais o casal confia no médic@, maior é o sentimento de que seu problema será resolvido, ainda que nem sempre seja assim.

As tecnologias, nesse sentido, são parte de processos mais gerais da transmutação da natureza em um âmbito de ação humana. Ao mesmo tempo, há um seqüestro da experiência, impossibilitando muitas vezes aos indivíduos tomar contato com o sucesso. Falar em confiança é falar de persistência, sendo necessário o engajamento dos sujeitos para chegar ao fim, ou seja, a ter um filho em casa.

b) o afeto apresenta-se como outro dos elementos fundamentais na relação com as NTRc - ele possibilita a permanência do casal no tratamento. Ora é apresentado como compensador da consciência sobre a falha técnica, ora como curativo dos traumas anteriores ao processo da FIV/ICSI, visto que esses procedimentos são sempre o último recurso disponível para os casais, que se submeteram a muitas outras formas anteriores de tratamento. $O$ coito programado, a medição de temperatura, a estimulação ovariana, até mesmo a inseminação artificial já lhes acrescentaram muito cansaço e até mesmo desesperanças.

c) a técnica é outro elemento fundamental, porque a reprodução assistida, entendida aqui a partir da IA, FIV e ICSI, 
${ }^{64}$ Segundo estudos da área médica, as transferências de embriões vêm merecendo maior atenção. Por exemplo, a introdução de meios de cultura sem glicose e sem fosfato como substituto de soro tem aumentado a chance de sucesso de $10 \%$ a $15 \%$. A retomada do estudo dos diferentes cateteres e o uso auxiliar de ultra-sonografia também contam como importantes, além da escolha do terceiro dia para transferência, o que permite uma boa seleção dos embriões a serem transferidos a fresco e, para os congelados, uma sobrevivên-cia com taxas de $15 \%$ a $20 \%$ de gravidez, que pode ser elevada com Assited hactching e retirada de blastômeros fragmentados (Renzo ANTONINI FILHO, 2002). demanda da parte médic@ outra entrada na vida do casal - fazer um filho a três ou a quatro. O médic@ irá decidir quanto medicamento, em geral, a mulher (embora nessa pesquisa haja relatos de uso de medicação por parte dos homens) irá tomar até o dia da ovulação (do amadurecimento folicular), o que lhe permitirá coletar o material genético para fazer o embrião.

Além do aspecto puramente técnico, o médic@ interfere na intimidade do casal. Ele está presente como regra, palavra e orientação. Ele necessita confiar que a mulher fará o caminho dos procedimentos propostos para que ele possa agir. Ele é um condutor da relação e, na FIV/ ICSI, assume realmente o fazer o filho.

d) qualidade do material - o discurso sobre a qualidade do material é imprescindível tanto para manter as expectativas de sucesso quanto para preparar o casal, quando o médic@ acha que não dará certo. Fala-se no número de folículos, na qualidade dos óvulos e espermatozóides, na qualidade dos embriões. Alerta-se para o fato de que esses elementos são fundamentais para obter um bebê. Esse comportamento, na maioria dos casos, impede que o casal se rebele contra outros fatores, como a tecnologia, o medicamento, as condições da clínica e do laboratório, o conhecimento médico, que jogam igualmente papel fundamental em relação aos resultados.

Além disso, há referência ao trabalho sobre uma chance hipotética como parte do próprio processo. Portanto, dizer que essa tecnologia é baseada no método das ciências naturais e dizer que ela é experimental não é uma postura ideológica negativa. É uma constatação. De fato, trata-se de uma tecnologia que trabalha sobre uma chance hipotética. Como não há padrões gerais a priori, os quais possam expressar a garantia de sucesso nas diferentes fases do procedimento, e como em cada caso (em relação à mulher) podem acontecer respostas diferentes, desde aquelas de ausência de ovulação, baixa ovulação, um resultado de hiperestimulação levando a problemas de saúde graves, até aquelas em que a qualidade macroscópica dos embriões pode se apresentar deficiente, ${ }^{64}$ há que se manter a expectativa em alta sobre a chance hipotética, o que implica necessariamente o engajamento das mulheres.

O médic@ trabalha com insegurança, embora persiga o sucesso. Como não domina todas as variáveis, ele joga com as possibilidades técnicas e com o desconhecimento genético.

Esse desconhecimento faz com que as decisões sejam tomadas na confiança de que darão certo, contando com o acaso, o que é dirimido pela atenção às respostas dadas através das comparações com as experiências 
anteriores. Há situações em que tudo traduz uma possibilidade de sucesso e ocorre o contrário, ou vice-versa, quando é esperado o insucesso e ocorre o sucesso.

Mesmo considerando que essa técnica é hipotética e experimental, as representações a positivam na medida em que as possibilidades por elas apresentadas são superiores às que são dadas pela natureza, pois passam de $15 \%$ para $35 \%$ do ciclo em relação às taxas de sucesso. No caso da ICSI, isso é um acréscimo significativo nas possibilidades de um casal vir a ter um filho, mas, por outro lado, é um fator estimulador e gerador de demanda. O fato de saber que existe tal tecnologia estimula e alimenta $o$ desejo de ter um filho. E o esclarecimento e o consentimento informados respaldam uma escolha de risco, se levadas em conta as estatísticas de sucesso.

e) pressão social e familiar - as NTRc se apresentam também como respostas para a pressão social e familiar e interferem solucionando os problemas do casal, e o médic@ se coloca na função de normalizador. Essa decisão médica de cumprir com sua função normalizadora não é, no entanto, arbitrária, à vontade do casal. Os médic@s buscam a gravidez que se configura fora do acaso, ao mesmo tempo em que permitem aos casais tomar uma decisão sobre quanto se envolver ou não se envolver. Eles crêem que essas tecnologias se constituem em um quadro de escolhas, e que os indivíduos que as procuram são mais conscientes, diferentes daqueles que se tornam pai e mãe sem o saber.

Além do mais, essas tecnologias vêm para resolver os problemas de desgaste e pressão social sobre o casal causados pelos longos anos sem filhos e pelos inúmeros tratamentos infrutíferos, além de permitir que esse casal, resgatando seu lugar socioparental, supere o caráter depressivo que o acompanha.

f) sexualidade - desse ponto de vista, a tecnologia pode diluir o desgaste com o sexo cronometrado, se considerados os tratamentos anteriores ligados à reprodução.

É absolutamente comum você ouvir que a relação sexual passa a ser meio de procriação. O sexo e o prazer na maioria deles já descolou completamente. Eles focam a relação no período fértil, ponto final. Então o companheirismo, a cumplicidade, a amizade, o dia-a-dia, às vezes está meio conflituado (médica, Rosita).

Fala-se claramente aqui de um sexo que não apenas funciona como uma norma, mas é parte de uma prática regulatória e que se manifesta como poder de produzir e fazer corpos, na intenção deliberada de fazer um filho.

Na fala dos casais, e particularmente na dos homens, 
a sexualidade é um dos aspectos que ficam absurdamente cindidos. Como um conjunto de experiências, ela se reduz, pelo menos durante a fase do tratamento para engravidar anterior à inseminação artificial, à fertilização in vitro e à injeção intracitoplasmática, ao sexo para fazer filho. Sexo para fazer filho adquire a cara do cronômetro. Essa fase do tratamento, a que chamamos de sexo cronometrado, é brochante, sempre relatada como uma péssima experiência.

Para os homens entrevistad@s, fazer inseminação ou FIV/ICSI é ruim, mas sexo para engravidar é "perder a tesão": "pensar em procriação deixa a cabeça zonza", "é coisa forçada", "abate o psicológico", "desgasta a relação". De alguma forma, é associado ao colher material sob pressão.

O sexual atrapalha bastante. A relação é o seguinte, sabe, o que é que prejudica quando ela está fazendo tratamento para engravidar. $O$ tratamento para inseminação é uma coisa, mas o tratamento para engravidar o que prejudica é que quando tu vais para a relação tu não vais definido para fazer amor, tu vais para engravidar. Tu vais pensando em procriação. Isso aí acontecia na minha cabeça. Chegou uma época que eu ia e ela ia, os dois. Eu sabia que ela estava fértil. A gente falava, ela dizia 'estou fértil hoje'. A gente tentava, mas era uma coisa muito forçada. Era uma dificuldade, o psicológico abate. Um dia que a [nome] me ligou dizendo: '[nome], tu tens que vir aqui. Porque estávamos assim, a doutora disse: 'olha, vocês fiquem uma semana sem ter relações'. Aí ela ligou para mim e disse: 'tu tens que vir aqui porque estão precisando do teu esperma'. Ela ligou da clínica para mim, eu estava com a minha roupa de serviço. Eu estava com minha roupa de trabalho, peguei o carro e fui para lá. Pô, não tinha jeito, meu Deus do céu. Eu já transpiro normalmente, eu transpirava o dobro. Tanto é que quando meu esperma saiu eu disse assim: 'meu Deus, que pouquinho'. Eu disse: '[nome], saiu tão pouquinho'. Eu deixei lá e fui embora para o trabalho, e a [nome] ficou lá para fazer a inseminação (Geraldo, casado com Janete).

O fator que é relatado como mais estressante para o homem é o de que ele se concebe como aquele que precisa ter prazer para ejacular. Mas essa performance fica comprometida pela falta de tesão, pelos apelos da esposa em horários considerados inoportunos, porque, segundo os homens, é muito ruim ter "uma obrigação de comparecer" para fazer sexo.

O sexo e o erotismo são submetidos ao imperativo da reprodução da espécie. Portanto, sem sexo e sem erotismo, a sexualidade se desvincula completamente da reprodução. A reprodução passa a ser uma construção físico-química a partir de um corpo produzido para fabricar 
${ }^{65}$ BUTLER, 1999.

células (óvulos), que, em união com outras (espermatozóides), resultarão na materialização de um embrião que será transferido e desenvolvido pelo corpo da mãe. O corpo da mãe é preparado para um dado desempenho seguindo normas regulatórias da atividade sexual, mas também é preparado pela medicação como efeitos materiais da norma cultural tecnológica que governa a materialização dos corpos. ${ }^{65}$ Desse modo, no caso das mulheres, as dificuldades com a busca do sexo e do prazer persistem também no tratamento com ICSI e FIV.

No começo eu tomei cloromide ou serofene, que contêm a mesma química. Então às vezes dava um estímulo e estimulava os ovários que eu não conseguia nem caminhar de tanta dor. Daí naquele dia eu tinha que ficar deitada e era fraquinho... E para fazer a inseminação injetável é o dobro, o triplo da medicação. É muito, eu tomei 30 injeções na barriga, todo o dia, todo dia, no braço e no bumbum, eu não sei se foi 10 ou 15 no meu braço. Deu vários caroços e hematomas, eu tinha que fazer compressas de água quente. Colocar as bolsas e foi inchando, o corpo foi inchando, a pele mudou, o cabelo, a unha. Transforma a gente, vira outra pessoa. Aí o que acontece? A gente vê o corpo da gente se transformando, estômago, porque é muita medicação, então a mente... A gente o que os olhos vêem, né, e a gente ficava assim... (Jadi, casada com Beto).

Já os homens, ao decidirem por FIV/ICSI, começam a relaxar quanto à necessidade de manter relações sexuais, exigidas anteriormente, e de certo modo essa decisão alivia as tensões. Em algumas situações, os entrevistad@s evitam o sexo porque, durante essa fase, o relacionamento se encontra conflitado devido ao desgaste com o tratamento hormonal exigido pelo processo de tratamento.

Em algumas falas, os casais parecem desejar fazer todo o bebê fora do corpo. Nesse caso, parece haver mesmo um endeusamento do poder da ciência, avaliando a lentidão da natureza e a capacidade tecnológica de interferir de modo eficaz. Eles desejariam ter ganhado tempo; consideram que perderam tempo, energia e dinheiro enquanto não tiveram acesso às NTRc. Ao mesmo tempo, os médic@s consideram que essas tecnologias também substituem etapas que teriam de ser vividas uma a uma na gestação natural, pois neste caso a mulher recebe o embrião pronto.

Para os médic@s, essas tecnologias se apresentam como fatores altamente estimuladores. Há uma sensação de estar no campo do moderno, junto com a possibilidade do estabelecimento de novas rotinas que permitam conhecer e acompanhar os desenvolvimentos tecnológicos. 
É muito legal, é muito interessante, e a bioética que está se estabelecendo em cima disso também é fascinante e interessante. Você hoje não tem algo tão rígido como se tinha antigamente em relação a algumas condutas. É algo bastante moderno para os médic@s, muitas rotinas estão se estabelecendo agora. Em relação a quantos embriões eu vou transferir, se podemos pegar mais de três ou quatro embriões em cada ciclo. Em que tipo de paciente a gente deveria transferir menos embriões. A gente acompanha no ultra-som os resultados dessas gravidezes, isso tudo eu acho muito legal (médico, José).

Esses aspectos aqui apresentados, embora sejam levados em conta todos os autores tratados na primeira parte deste artigo, permitem pensar sobre o papel das técnicas e tecnologias de laboratório no desenvolvimento, produção e exploração dos fatos sociocientíficos e reconhecer que os procedimentos necessários à concepção foram deslocados para a clínica ou laboratório. Isso demanda outras formas de controle que não apenas as normas e os valores relativos ao corpo médico ou ao foro das decisões individuais.

Esses procedimentos, além de terem um ancoramento técnico-científico, exigem da parte dos envolvidos atitudes de confiança, de afeto, de manutenção das expectativas e de perseverança. Sem a intervenção desses aspectos, que supõem envolvimentos afetivos e emocionais, além de recursos econômicos, o campo biomédico não encontraria caminho para a sua ação.

Assim, a confiança na técnica e no médic@ funciona como elemento propulsor da realização do tratamento. A persistência do casal é considerada pelos médic@s como elemento fundamental ao sucesso. A expressão 'qualidade do material' e a preocupação com a existência ou não de folículos marcam as expectativas quanto a resultados positivos ou negativos. Ao mesmo tempo que caracteriza os riscos de insucesso, constrói decisões sobre tentar fazer o maior número possível de embriões.

Quanto à relação desses aspectos e seus sentidos com os desafios éticos/bioéticos, considere-se - para além do quadro das questões cotidianas do tratamento, que dizem respeito bem de perto à deontologia médica - que existem as pressões sociais e familiares sobre os casais, o quase apagamento de outras possibilidades de construção e reapropriação das desigualdades de gênero e da constituição de relações com as crianças.

Precisamos considerar ainda que a natureza fértil continua sendo construída enquanto duram os esforços e o desejo na busca pelo filho. É essa busca que permite desenvolver o que os médic@s chamam de relação de 
ajuda e todas as formas de intervenção necessárias à constituição dessa relação. Como um continuum entre o social, o cultural e o político, as relações estabelecidas entre médic@s, pacientes e laboratórios, pacientes e pacientes, médic@se médic@s,médic@s e técnicos, forjam os imbricados caminhos desse processo.

Possivelmente, também tendo em vista a capacidade manipulatória sobre células e embriões, abrem-se campos novos de intervenção e de descontinuidades fundamentais naquilo que era considerado o tempo linear da vida.

O fato de as NTRc no Brasil serem pagas e desenvolvidas, em sua grande parte, no segredo da relação médico/paciente em clínicas privadas, diz respeito diretamente ao campo dos direitos sexuais e reprodutivos. Da mesma forma, elas não são igualmente acessíveis a todos, por concepções sobre a família que se refletem na interdição a mães solteiras e a casais homossexuais.

Problematizamos o fato de que o querer do casal seja apresentado como legitimador de todas as formas de intervenção e de que o médic@ insista em manter a neutralidade técnica, embora ele seja a única autoridade a decidir sobre a interrupção ou sobre a continuidade do tratamento. As dificuldades que se impõem para casais e médic@s na hora de administrar as frustrações de um ciclo perdido ou diante da constatação de erros nos procedimentos que induziram a insucessos são aspectos importantes que nos desafiam a pensar nas regras de relacionamento entre médic@s e casais, aspectos que não podem ser definidos apenas por comitês de ética ou se resumir a regras de experts, devido aos inúmeros conflitos relatados pelos entrevistad@s.

Não se trata apenas de manter um posicionamento contrário a todas as formas eugênicas e racistas, já tão denunciadas, mas de escolher responsavelmente a própria forma de viver. Para que isso ocorra, é necessária a ampliação da discussão pública desses fatos biotécnicocientíficos (biotecnológicos) e das condições de gênero em que eles são desenvolvidos.

É mister fazê-los sair do anonimato para que possam gerar conhecimentos partilhados e para prevenir novas culpabilizações, visto que em grande parte encontram sua legitimidade no desejo de filhos por parte das mulheres. Denunciar isso em termos de dominação masculina, como fazem algumas vertentes do feminismo, por exemplo, é pouco útil para a necessidade de amadurecimento teórico e social a respeito da pluralidade e da multiplicidade de possibilidades geradas por esse desenvolvimento tecnológico. É possível que, além da migração de um 
conhecimento biomédico para a linguagem de um casal o que substitui as relações sexuais reprodutivas pela tecnologia -, estejam acontecendo ainda outras transformações.

As NTRc podem estar sendo verdadeiramente ampliadoras de possibilidades técnico-científicas, mas são, ao mesmo tempo, altamente excludentes e geradoras de muitas novas angústias. Possibilitar espaços de explicitação e discussão dessas questões parece ser fundamental. Como provocar reflexão sobre essas decisões e não publicizar o modo como esses campos verdadeiramente se constituem (seus riscos, seus interesses e seus custos)?

O que observamos é que, proeza para alguns, ameaça para outros, a artificialização da procriação humana ocupa um lugar singular dentro do movimento obscuro das ciências da vida. Cada um pode sentir que o que está em jogo é muito mais do que a esterilidade tubária ou qualquer outra - são os sentidos de demandas nem sempre identificáveis. São jogos empapados pelos interesses mercadológicos e tecnológicos e que muitas vezes se contrapõem no tabuleiro das escolhas e dos direitos. São interesses que incluem o mercado, com suas trocas e equipamentos, os bancos de esperma, as universidades e centros médicos, que mantêm o pagamento, o governo, que promulga as pesquisas, as apólices de seguro, conforme

${ }^{66}$ BECKER, 2000. Gay Becker. ${ }^{66}$ Essa é uma longa lista de interesses que demonstram quanto poder e quanto dinheiro estão em jogo, e como as NTRc representam grandes negócios.

Ao pensarmos sobre NTRc, constatamos que o desenvolvimento tecnológico é ponto fundamental em relação a essas formas de tratar e de constituir família, e pode-se mesmo dizer que há uma decalagem históricotemporal entre os avanços científicos (tome-se em particular o desenvolvimento genético/molecular) e as formas de organização social em famílias estruturadas na consangüinidade e na autoridade parental. A reprodução assistida está no centro das relações de gênero, atravessadas pelas preocupações contemporâneas sobre a família e as novas formas de parentalidade.

\section{Referências bibliográficas}

ANTONINI FILHO, Renzo. Comentários sobre o $53^{\circ}$ Congresso da Sociedade Americana de Medicina Reprodutiva. Disponível em: http://www.profert.com.br. Acesso em: 31 mar. 2002.

ARILHA, Margareth. "Homens: entre a 'zoeira' e a 'responsabilidade'”. In: ARILHA, Margareth; RIDENTI, Sandra; MEDRADO, Benedito. Homens e masculinidades: outras palavras. São Paulo: Ecos/Editora 34, 1998. p. 51-78. 
ÁVILA, Maria Betânia. "Direitos reprodutivos: uma invenção das mulheres reconhecendo a cidadania". Mandrágora: Direitos Reprodutivos, Religião e Ética, São Bernardo do Campo/SP: Núcleo de Estudos Teológicos da Mulher na América Latina (NETMAL)/Católicas pelo Direito de Decidir/ SOS Corpo, ano 4, n. 4, p. 11-26, 1997.

"Direitos reprodutivos, exclusão social e AIDS". In: BARBOSA, Maria Regina; PARKER, Richard (Orgs.). Sexualidades pelo avesso: direitos, identidade e poder. Rio de janeiro: IMS/UERJ; São Paulo: Editora 34, 1999. p. 39-48.

BATEMAN, Simone. "La Responsabilité medicale aux frontieres de l'activite therapeutique: les cas de l'assistance medicale a la procréation". In: IACUB, Marcela; JOUANNET, Pierre. Juger la vie: les choix médicaux en matière de procréation. Paris: Editions La Decouvert, 2001. p. 111-126.

. "La Bioéthique comme objet sociologique". Cahiers Internationaux de Sociologie, Paris: CNRS, n. CIV, p. 532, 1998.

. Éthique et assistance médicale à la procréation. Paris: Elsevier, 1999. (Encyclopédie Médico-Chirurgicale, Gynécologie, 755-A-30).

BECKER, Gay. The Elusive Embryo HowWomen And Men Approch New Reproductive Techonologies. Berkeley/Los Angeles/London: University of California Press, 2000.

BRASIL. Conselho Federal de Medicina. Resolução n. 1.358, de 19 de novembro de 1992. Normas éticas para a utilização das técnicas de reprodução assistida. Diário Ocicial da União, Brasília, 1992. p. 1653.

BOLETIM ELETRÔNICO SAÚDE REPRODUTIVA NA IMPRENSA. Edição de 1 a 15 de abril de 2000.

BUTLER, Judith. "Corpos que pesam: sobre os limites discursivos do 'sexo'”. In: LOURO, Guacira Lopes (Org.). O corpo educado: pedagogias da sexualidade. Belo Horizonte: Autêntica, 1999. p. 150-172.

CHATEL, Marie-Magdeleine. Malaise dans la procréations: les femmes et la médecine de l'enfantement. Paris: Editions Albin Michel, 1998.

CORRÊA, Marilena Villela. "As novas tecnologias reprodutivas: uma revolução a ser assimilada". PHYSIS: Rev. Saúde Coletiva, Rio de Janeiro: IMS/UERJ;CEPESC/ EDUERJ, v. 7, n. 1, p. 69-98, 1997.

. "Reprodução assistida. Regulação possível? Quem controla o quê e como?" Jornal do Conselho Federal de Medicina, Brasília: Conselho Federal de Medicina, ano XV, n. 116, p. 8-9, abr. 2000.

. Novas tecnologias reprodutivas: limites da biologia ou biologia sem limites? Rio de Janeiro: Ed. UERJ, 2001. COSTA, Sérgio; DINIZ, Débora. Introdução à bioética: ensaios. Brasília: Letras Livres, 2001. 
DHAVERNAS, Marie-Josèphe Levy. "Reproduction médicalisée, temps et différence". Cahiers du Genre, Paris: Editions L'Harmattan, n. 25, p. 167-188, 1999. Coordonné par Madeleine Akrich et Francoise Laborie.

DINIZ, Débora. "Tecnologias reprodutivas, ética e gênero: o debate legislativo brasileiro". Série Anis, Brasília, n. 15, p. 1-23, 2000.

DINIZ, Debora; BUGLIONE, Samantha. (Orgs.). Quem pode ter acesso às tecnologias reprodutivas: diferentes perspectivas do Direito Brasileiro. Brasília: Letras Livres, 2002.

DINIZ, Débora; GUILHEM, Dirce. O que é bioética? São Paulo: Brasiliense, 2002.

DORA, Denise Dourado. "Direitos sexuais, direitos reprodutivos e direitos humanos: conceitos em movimento". In: ARILHA, Margareth; CITELI, Maria Tereza (Orgs.). Políticas, mercado, ética: demandas e desafios no campo da saúde reprodutiva. São Paulo: Editora 34, 1998. p. 6980.

FAURE- PRAGIER, Sylvie. "En Finir avec la stérilité psychogène: pour une théorie de l'inconception". CAHIERS de Maternologie. Revue de la Maternité Pyschique. Bébé 2000 les Révolutions de la Parenté, Paris, n. 11, p. 55-61, juil./déc. 1998.

. Les Bébes de l'inconscient: les psychanalyste face aux stérilités féminines aujourd'hui. Paris: PUF, 1999.

FRAISSE, Geneviève. "Entre igualdade e liberdade". Revista Estudos Feministas, Rio de Janeiro: FCS/UFRJ; PPCIS/UERJ, v. 3, n. 1, p. 164-171, 1995.

FRANCO JUNIOR, José Gonçalves. Dilemas de la reproduccion asistida. Disponível em: http:// www.scielo.br/scielo. Acesso em: 8 ago. 2002.

FRANKLIN, Marilyn. "Deconstructing 'Desperateness': the Social Construction of Infertility in Popular Representations of New Reproductive Techonologies". In: MCNEIL, Maureen, VARGOE, lan, and YEARLEY, Steven. The New Reproductive Technologies. London: The Macmillan Press, 1990. Cap. 8.

GIDDENS, Anthony. Modernity and Sel-Identity. London: Polity Press, 1991. p. 1-9, p. 36-37, p. 126-137.

IACUB; Marcela; JOUANNET, Pierre. "Introduction: les choix médicaux en matière de procréation". In: _.. Juger la vie: les choix médicaux en matière de procréation. Paris: Éditions la Découverte, 2001. p. 5-14.

JOUANNET, Pierre. "Le médicin face à la procréation légalement assistée". In: IACUB, Marcela; JOUANNET, Pierre. Juger la vie: les choix médicaux en matière de procréation. Paris: Éditions la Découverte, 2001. p. 127-139.

LABORIE, Françoise. "Les Femmes objets d'experimentation". CAHIERS du Feminisme, Paris: Printemps, n. 59/60, p. 3033, 1992a. (Dossier, entretien). 
"Rapports sociaux de sexe dans les nouvelles technologies de la reproduction". Cahiers du GEDISST. Paris: L'Hamattan, n. 3, p. 26-34, 1992b.

"Procréation artificielle: de quelle politique reproductive s'agit-il?" Cahiers du GEDISST. Paris: IRESCO/ GEDDISST/CNRS, n. 5, p. 43-60, 1992c.

. "Novas tecnologias da reprodução: risco ou liberdade para as mulheres?" Tradução de Vera Pereira e Gisélia Potengy. Revista Estudos Feministas, Rio de Janeiro: CIEC/ ECO/UERJ, v. 1, n. 2, p. 435-447, 1993.

"Nouvelles tecnologies de la reproduction (NTR): risques pour la santé des enfants". In: LES MODES DE RÉGULATION DE LA REPRODUCTION HUMAIN. INCIDENCES AUR LA FECONDITÉ ET LA SANTÉ. Colloque International de Delphes, 6-10 oct. 1992; Colloque de L'AIDELF, 4, Paris: PUF, 1994a. p. 771-777.

. "Nouvelles techonologies de la reproduction (NTR): risques pour la santé des femmes. In: LES MODES DE RÉGULATION DE LA REPRODUCTION DE LA REPRODUCTION HUMAIN. INCIDENCES SUR LA FECONDITÉ ET LA SANTÉ. Colloque International de Delphes, 6-10 oct. 1992; Colloque de L'AIDELF, 4, Paris: PUF, 1994b. p.757-770.

"Procréation artificielle: santé des femmes et des enfants". In: SANTE ET MORTALITÉ DES ENFANTS EN EUROPE/ CHILD HEALTH AND MORTALITY IN EUROPE. Chaire Quetelet 1994. Louvain - La Neuve, Institut de Démographie, Ecole de Santé Publique UCL-ULB. Louvain - La Neuve: Academia Bruylant; Paris: L'Harmattan/CNRS/IRESCO/ GEDISST, 1996. p. 477-500.

. "Construction conjointe des techniques procréatives et du genre. Comparaison entre FIV et ICSI". In: LA RECHERCHE FÉMINISTE DANS LA FRANCOPHONIE. ETAT DE LA SITUATION ET PISTES DE COLLABORATION. Communication présentée à la table ronde "Constrution sociale des techniques et du genre". Université Laval, Québec, 24-28 sept. 1996. Montreal: Ed. Du RemueMénage, 1999. p. 1- 19.

. "Gender-Based Management of New Reproductive Technologies: a Comparison between in vitro Fertilization and Intracytoplasmic Sperm Injection." In: SAETNAN, Ann Rudinow, OUDSHOORN, Nelly, and KIREJCZYK, Marta. Bodies of Techonology: Women's Involvement with Reproductive Medicine. Georgia: Ohio State University, 2000. p. 278-303.

LABORIE, Francoise; AKRICH, Madeleine. "De la contraception à l'enfantement. L'offre techonologique en question". Cahiers du Genre, Paris: Editions L'Harmattan, n. 25 , p. 5-16, 1999.

. "Tecnologies de la reproduction humaine". In: HIRATA, Helena; LABORIE, Françoise; LE DOARE, Hélène; SENOTIER, 
Daniele. (Coords.). Dictionnaire critique du féminisme. Paris: PUF, 2000. p. 220-225. Politique D'aujourd'hui.

LENOIR, Noëlle. "La fabrication de l'humain, la médecine du futur et l'éthique". In: MELLA, Mario (Ed.). Éthique et société. Paris: Edition Éthique et Societé, 2001. p. 19-43.

MATTEI, Jean-François; LABORIE, Françoise; NOVAES, Simone. "Dilemmes de la procréation assistée. Rencontre entre un médicin parlamentaire et deux sociologues". Natures - Sciences - Sociétés, Paris, v. 3, n. 3, p. 236-245, 1995.

MEHL, Dominique. "Bioéthique. Revue de presse". In: FRYDMAN, René; FLIS-TRÉVES, Muriel; KOEPPEL, Béatrice. Les procreations médicalement assistées: vingt ans apprès. Paris: Editions Odile Jacob, 1998. p. 151-174.

MOTA, Antonio Joaquim; OLIVEIRA, Fátima de. Rede Nacional Feminista de Saúde e Direitos Reprodutivos. São Paulo: Redesaude, 2000. Dossiê "Bioética e as mulheres: por uma bioética não sexista, anti-racista e libertária".

NOGUEIRA, Danielle. "Identidade biológica ou afetiivdade?: projeto obrigando mães que receberam embriões a revelar pais biológicos divide os cientistas". Jornal do Brasil, Rio de Janeiro, 22 set. 2000. Disponível em: http:/ /www.widesoft.com.br/cgibin/majordomo/subscribe/ bioetica.html. Acesso em: 22 set. 2000.

OLIVEIRA, Fátima. Bioética: uma face da cidadania. São Paulo: Moderna, 1997.

. Lista bioética feminista. Disponível em: http:// www. widesoft.com.br/cgi-bin/majordomo/subscribe/ bioetica.htm. Acesso em: 24 ago. 2001.

. "Novas Tecnologias Reprodutivas Conceptivas (NTRc): as benesses, os problemas e os riscos". In: Lista de bioética. Tema do mês de maio de 2000. Disponível em: http://www.widesoft.com.br/cgi-bin/majordomo/ subscribe/bioetica.htm. Acesso em: 30 jun. 2000.

PHARO, Patrick. Nature, culture et significations dans la theories de l'homme. Paris: CNRS/CERSES, 2001. Notes de l'exposé du 9 octobre, 2001.

PEREIRA, Dirceu Henrique. "Reprodução assistida". Revista Época. Disponível em: http://www.epoca.com.br/edic/ ed07082000/socila.htm. Acesso em: 7 ago. 2000.

- Como aumentar o índice de implantação embrionária. Disponível em: http://www.profert.com.br. Acesso em: 31 mar. 2002.

PEREIRA, Wilza Rocha. "O processo de medicalização do corpo feminino". In : SCAVONE, Lucila; BATISTA, Luiz Eduardo (Orgs.). Pesquisas de gênero: entre o público e o privado. São Paulo: UNESP/Cultura Acadêmica, 2000. p. 127-142.

PETCHESKY, Rosalind Pollack. Direitos sexuais: um novo conceito na prática política internacional. In: BARBOSA, Regina Maria; PARKER, Richard. Sexualidades pelo 
avesso: direitos, identidades e poder. Rio de Janeiro: IMS-UERJ/Editora 34, 1999. p. 15-38.

PISCITELLI, Adriana. "Nas fronteiras do natural: gênero e parentesco". Revista Estudos Feministas, Rio de Janeiro: IFCS/UFRJ, v. 6, n. 2, p. 305-321 1998a.

. "Gênero em perspectiva". Cadernos Pagu, Campinas/São Paulo: Núcleo de Estudos de Gênero/ UNICAMP, n. 11, p. 141-155, 1998b.

RENDTTORFF, Jacob Dahl, and KEMP, Peter. "Introduction: Description of the Basic Ethical Principles in Bioethics and Biolaw. Basical Ethical Principles". In: EUROPEAN BIOETHICS AND BIOLAVE. Report to the European Commission of the Biomed - II Project. Basic Ethical Principles in Biothics and Biolaw 1995-1998. Copenhagen, Jan. 2000. v. 1.

RIBEIRO, Diaulas Costa. "Reprodução medicamente assistida: parentalidade contratual e biológica - controvérsia e certificações". In: DINIZ, Debora; BUGLIONE, Samantha (Orgs.). Quem pode ter acesso às tecnologias reprodutivas: diferentes perspectivas do Direito Brasileiro. Brasília: Letras Livres, 2002. p. 33-49.

ROTANIA DE POZZI, Alejandra Ana. "Vertientes valorativas actuales frente a las nuevas tecnologias reproductivas". In: SCAVONE, Lucila. Género y salud reproductiva en América Latina. Cartago, Costa Rica: LUR, 1999. p. 333368.

ROUCH, Hélène. "Nouvelles techniques de reproduction: de la différence à l'inégalité". In: HURTIG, Marie-Claude; KAIL, Michèle; ROUCH, Hélène. Sexe biologique et sexe social. Paris: CNRS Editions, 2002. p. 245-255.

SAETNAN, Ann Rudinow. "Women's Involvement with Reproductive Medicine: Introducing Shared Concepts." In: SAETNAN, Ann Rudinow, OUDSHOORN, Nelly, and KIREJCZYK, Marta (eds.). Bodies of Technology: Women's Involvement with Reproductive Medicine. Georgia: Ohio State University Press, 2000. p. 1-30.

SCAVONE, Lucila. "Anticoncepción, aborto y tecnologias conceptivas: entre la salud, la etica y los derechos". In: . Género y salud reproductiva en América Latina. Cartago, Costa Rica: LUR, 1999. p. 21-56.

SOARES, Vera. "Trabalhadoras: direitos reprodutivos nos acordos coletivos". In: COSTA, Albertina Oliveira. Direitos tardios: saúde, sexualidade e reprodução na América latina. São Paulo: Fundação Carlos Chagas/Editora 34, 1997. p. 89-114.

SOMMER, E. Susana. "Nuevas formas de procréación". In: SCAVONE, Lucila (Org.). Género y salud reproductiva en América latina. Costa Rica: Livro Universitário Regional, 1999. p. 307-332.

TAIN, Laurence. "Techiniques et acteurs: parcours différencies de femmes dans une démarche de fécondation in vitro". Cahiers du Genre, Paris: Éditions l'Harmattan, n. 25 (De 
la contraception à l'enfantement: L'offre technologique en question), p. 75-94, 1999. Coordonné par Madeleine Akrich et Francoise Laborie.

TAMANINI, Marlene. Novas Tecnologias Reprodutivas Conceptivas à luz da bioética e das teorias de gênero: casais e médic@s no Sul do Brasil. 2003.363 p. Tese (Doutorado no Programa Interdisciplinar em Ciências Humanas, Linha Estudos de Gênero) - Centro de Filosofia e Ciências Humanas, Universidade Federal de Santa Catarina, Florianópolis.

TELLES, Fábio. "Desenvolvida técnica para fecundação de óvulo sem esperma". O Estado de S. Paulo. Disponível em: http://www.estadao.com.br/ciencia/noticias/2001/jul/ 10/216.htm. Acesso em: 10 jul. 2001.

TESTART, Jacques. Des hommes probables: de la procréation aléatoire à la reproduction normative. Paris: Editions du Seuil, 1999.

TESTARD, Jacques; GODIN, Christian. Au bazar du vivant: biologie, médicine et bioéthique sous la coupe libérale. Paris: Éditions du Seuil, 2001.

TUBERT, Silvia. Mulheres sem sombra: maternidade e novas tecnologias reprodutivas. Rio de Janeiro: Rosa dos Tempos, 1996.

VAN DER PLOEG, Irma. "Lindividualité féminine à l'épreuve des techonologies de reproduction". Cahiers du Genre, Paris: Éditions L'Harmattan, n. 25 (De la contraception à l'enfantement: L'offre technologique en question), p. 95121,1999 . Coordonné par Madeleine Akrich et Francoise Laborie.

[Recebido em abril de 2003 e aceito para publicação em dezembro de 2004]

\begin{abstract}
New Reproductive Conception Technologies: Bioethics and Controversies
Abstract: This article concerns some of the multiple ethical-bioethical and gender issues in the field of new reproductive and contraceptive technologies. The literature presented points to the plurality of possible situations and approaches in a multidimensional and controversial field. It presents some ethical-bioethical principals of biomedical action found in the study of heterosexual couples who use assisted reproduction. and of medical specialists in human reproduction in southern Brazil. It presents the ethical-bioethical presumptions that sanction medical behavior and the continuity of the so-called impregnation treatments, and analyzes the mechanisms used to raise the expectations of couples who lack confidence or success. Key words: contraceptive technologies, bioethics, medical deontology, gender.
\end{abstract}

